\title{
Smoking is Not a Good Prognostic Factor following First-Ever Acute Ischemic Stroke
}

\author{
Ju-Hun Lee, Ju Young Lee, So Hyun Ahn, Min Uk Jang, Mi Sun Oh, Chul-Ho Kim, Kyung-Ho Yu, \\ Byung-Chul Lee \\ Department of Neurology, Hallym University Medical Center, Hallym Neurological Institute, Hallym University College of Medicine, Anyang, Korea
}

Background and Purpose There is evidence that smoking increases stroke risk; however, the effect of smoking on functional outcome after stroke is unclear. The aim of this study was to explore the effect of smoking status on outcome following acute ischemic stroke.

Methods We assessed 1,117 patients with first-ever acute cerebral infarction and no prestroke disability whose functional outcome was measured after three months. A poor outcome was defined as a modified Rankin Scale score of $\geq 2$. Smoking within one month prior to admission was defined as current smoking. Our analysis included demographics, vascular risk factors, initial National Institutes of Health Stroke Scale (NIHSS) score, stroke subtype, onset-to-admission time, thrombolytic therapy, initial blood pressure, and prognostic blood parameters as covariates.

Results At baseline, current smokers were predominantly male, approximately 10 years younger than non-smokers (mean age, 58.6 vs. 68.3 years), and less likely to have hypertension and atrial fibrillation ( $53.9 \%$ vs. $65.4 \%$ and $8.7 \%$ vs. $25.9 \%$, respectively), with a lower mean NIHSS score (4.6 vs. 5.7). The univariate analyses revealed that current smokers had a better functional outcome and significantly fewer deaths at three months follow-up when compared with non-smokers (functional outcome: $64.0 \%$ vs. 58.4\%, $P=0.082$; deaths: $3.0 \%$ vs. $8.4 \%, P=0.001$ ); however, these effects disappeared after adjusting for covariates $(P=0.168$ and $P=0.627$, respectively).

Conclusions In this study, smoking was not associated with a good functional outcome, which does not support the paradoxical benefit of smoking on functional outcome following acute ischemic stroke.

Keywords Smoking; Acute ischemic stroke; Prognosis

\author{
Correspondence: Byung-Chul Lee \\ Department of Neurology, Hyllym \\ Neurological lustitute, 22 Gwanpyeong-ro \\ 170 beon-gil, Anyang 431-796, Korea \\ Tel: $+82-31-380-3741$ \\ Fax: +82-31-381-4659 \\ Email: ssbrain@hallym.ac.kr \\ Received: January 15, 2015 \\ Revised: March 24, 2015 \\ Accepted: March 25, 2015
}

This study was supported by a grant from the Korea Health 21 RED Project, Ministry of Health, Welfare and Family Affairs, Republic of Korea (HI10C2020).

The authors have no financial conflicts of interest.

\section{Introduction}

Smoking is a modifiable and established risk factor for stroke. ${ }^{1,2}$ The age-standardized prevalence of current smoking in Korean adults is substantially high when compared with the US population, in particular in men ( $48.1 \%$ of Korean men vs. $21.2 \%$ of US men). ${ }^{3,4}$ The population attributable risk of smoking for stroke is also high in Korean men (26.5\%). ${ }^{5}$ Therefore, antismoking cam- paigns are an important health-related intervention for stroke prevention in Korea.

Despite the increased risk of stroke from smoking, there is debate regarding its effect on functional outcome following acute ischemic stroke. Current smoking prior to stroke is a poor ${ }^{6-8}$ or neutral prognostic factor according to the results of some studies. ${ }^{9-13}$ Surprisingly, smoking has been reported as a beneficial prognostic factor in acute ischemic stroke. ${ }^{1417}$ It is postulated that 
chronic exposure to smoking or nicotine may promote angiogenesis or ischemic preconditioning with enhanced collateral flows. In addition, there might be a greater susceptibility to spontaneous or therapeutic thrombolysis of cerebral thrombi in smokers.

Due to these conflicting results, we aimed to explore whether cigarette smoking was independently associated with the functional outcome of patients after acute ischemic stroke using our prospective registry database. In addition, we investigated whether any smoking effect differed across subgroups, including ischemic stroke subtypes.

\section{Methods}

\section{Study design and subjects}

Subjects were consecutive patients with first-ever ischemic stroke and without previous functional disability (modified Rankin Scale [mRS] score >1) who were admitted to Hallym University Medical Center within 7 days of symptom onset between October 2007 and July 2012. The data were populated from the Hallym Stroke Registry, a prospective hospital-based stroke database. The Institutional Review Board of Hallym University Medical Center approved the stroke registry and waiver of informed consent from registered patients. Patient information was anonymized and de-identified prior to analysis. Of the 1,248 patients who met our inclusion criteria, we excluded 131 patients $(10.5 \%)$ because they did not have 3-month functional outcome data. Therefore, 1,117 subjects were included in the outcome analysis.

\section{Smoking status and covariate factors}

We defined current smokers as those with any history of smoking within one month prior to index stroke. We subdivided nonsmokers into former-smokers and never-smokers. Former-smokers did not smoke at least one month before the index stroke and never-smokers were those with no smoking history.

We included the following covariates in our analysis: demographics, body mass index (BMI), vascular risk factors, initial National Institutes of Health Stroke Scale (NIHSS) score, stroke subtype (according to Trial of ORG 10172 in Acute Stroke Treatment [TOAST] criteria), onset-to-admission time, tissue plasminogen activator (tPA) therapy, mean value of initial systolic blood pressure (systolic BP), and prognostic blood parameters including blood glucose, low density lipoprotein (LDL) cholesterol, white blood cell (WBC) count, and hemoglobin count. Blood glucose and LDL cholesterol were measured in a fasting state during the first morning after admission.

Hypertension was assigned based on the presence of one or more of the following: history of hypertension and antihyperten- sive medication, repeated BP measurements $>140 / 90 \mathrm{mmHg}$ at 1 week intervals, or evidence of hypertensive damage on echocardiogram. Diabetes was assigned if there was a history of diabetes mellitus while also receiving anti-hyperglycemic therapy, fasting blood glucose level $>126 \mathrm{mg} / \mathrm{dL}$, or postprandial blood glucose level $>200 \mathrm{mg} / \mathrm{dL}$. Hyperlipidemia was assigned if there was a history of hyperlipidemia with concurrent pharmacotherapy or fasting LDL cholesterol level $>160 \mathrm{mg} / \mathrm{dL}$ (or total cholesterol $>240 \mathrm{mg} / \mathrm{dL}$ if LDL was not available).

\section{Outcome assessment}

Functional outcome and death were assessed at three months after stroke through face-to-face or telephone interview with patients or caregivers. Functional outcome was measured by mRS. A poor functional outcome was defined as an $\mathrm{mRS}$ score $\geq 2$.

\section{Statistical analysis}

We compared the baseline characteristics of current smokers with non-smokers, former-smokers, and never-smokers (Table 1). We also compared the baseline characteristics of patients with a 3 month post-stroke mRS score available and those lost to follow-up (Supplementary Table 1 ). The $\chi^{2}$ test and $t$ test were used for categorical and continuous variables, respectively. NIHSS scores were split into quartiles. We divided BMI into high $\left(\geq 25 \mathrm{~kg} / \mathrm{m}^{2}\right)$, normal $\left(<25\right.$ but $\left.>20 \mathrm{~kg} / \mathrm{m}^{2}\right)$, and low BMI $\left(\leq 20 \mathrm{~kg} / \mathrm{m}^{2}\right)$.

Univariate and binary logistic regression analyses were used to determine the association between smoking status and functional outcome at three months. All variables in the univariate analysis were included in the multivariate analysis because they were potential prognostic factors. Small vessel disease was regarded as the reference among stroke subtypes. Those with undetermined and other determined stroke subtypes were not included in the univariate and multivariate analyses.

We also evaluated the effect of smoking through subgroup analysis of sex, age, stroke subtype, risk factors (hypertension, diabetes mellitus, hyperlipidemia, and atrial fibrillation), BMI, and tPA therapy.

We excluded the cases with missing data from all analyses. The significance level was set at $P<0.05$ for all statistical analyses.

\section{Results}

\section{Baseline characteristics}

The 1,117 patients included 639 men (57.2\%) and 487 women with a mean age of $65.3( \pm 13.5)$ years. Median NIHSS was 3 (interquartile range 1-7). Mean onset-to-admission time was $28.6( \pm 37.1)$ hours. Data for atrial fibrillation were missing in 3 
Table 1. Baseline characteristics according to smoking habit

\begin{tabular}{|c|c|c|c|c|c|c|c|}
\hline Parameters & $\begin{array}{l}\text { Current smokers } \\
\qquad n=336\end{array}$ & $\begin{array}{c}\text { Non-smokers } \\
\mathrm{n}=777\end{array}$ & $P$ value & $\begin{array}{c}\text { Former smokers } \\
\qquad n=126\end{array}$ & Pvalue* & $\begin{array}{c}\text { Never-smokers } \\
n=651\end{array}$ & $P$ value \\
\hline Onset-to-admission time (hour), (mean \pm SD) & $28.6 \pm 37.2$ & $28.6 \pm 37.2$ & 0.974 & $23.9(30.5)$ & 0.167 & $29.5 \pm 38.3$ & 0.749 \\
\hline Males, $\mathrm{n}(\%)$ & $308(91.7)$ & $328(42.2)$ & $<0.001$ & $119(94.4)$ & 0.315 & $209(32.1)$ & $<0.001$ \\
\hline Age (mean \pm SD) & $58.6 \pm 12.8$ & $68.3 \pm 12.7$ & $<0.001$ & $67.1(11.4)$ & $<0.001$ & $68.5 \pm 12.9$ & $<0.001$ \\
\hline Body mass index $\left(\mathrm{kg} / \mathrm{m}^{2}\right)$, (mean $\left.\pm \mathrm{SD}\right)$ & $23.7 \pm 3.0$ & $23.7 \pm 3.3$ & 0.821 & $24.2(3.1)$ & 0.098 & $23.6 \pm 3.3$ & 0.833 \\
\hline High BMI ( $\geq 25), n(\%)$ & $108(32.9)$ & $246(32.7)$ & 0.988 & $45(36.9)$ & 0.670 & $201(31.9)$ & 0.913 \\
\hline Normal BMI, $\mathrm{n}(\%)$ & $187(57.0)$ & $428(56.9)$ & & $67(54.9)$ & & $361(57.3)$ & \\
\hline Low BMI (<20), n (\%) & $33(10.1)$ & $78(10.4)$ & & $10(8.2)$ & & $68(10.8)$ & \\
\hline Hypertension, $\mathrm{n}(\%)$ & $181(53.9)$ & $508(65.4)$ & $<0.001$ & $85(67.5)$ & 0.008 & $423(65.0)$ & $<0.001$ \\
\hline Diabetes Mellitus, $\mathrm{n}(\%)$ & $99(29.5)$ & $230(29.6)$ & 0.963 & $41(32.5)$ & 0.522 & $189(29.0)$ & 0.999 \\
\hline Hyperlipidemia, n (\%) & $107(31.8)$ & $225(29.0)$ & 0.334 & 42 (33.3) & 0.761 & $183(28.1)$ & 0.427 \\
\hline Atrial fibrillation, $\mathrm{n}(\%)$ & $29(8.7)$ & $201(25.9)$ & $<0.001$ & $27(21.6)$ & $<0.001$ & $174(26.8)$ & $<0.001$ \\
\hline \multicolumn{8}{|l|}{ Stroke subtype, n (\%) } \\
\hline Large artery disease & $123(36.6)$ & $215(27.7)$ & $<0.001$ & $42(33.3)$ & 0.034 & $173(26.6)$ & $<0.001$ \\
\hline Small vessel disease & $121(36.0)$ & $238(30.6)$ & & $32(25.4)$ & & $206(31.6)$ & \\
\hline Cardioembolism & $46(13.7)$ & $196(25.2)$ & & $23(18.3)$ & & $173(26.6)$ & \\
\hline Undetermined & $28(8.4)$ & $81(10.4)$ & & $19(15)$ & & $62(9.5)$ & \\
\hline Other determined & $18(5.4)$ & $47(6.0)$ & & $10(7.9)$ & & $37(5.7)$ & \\
\hline Received tPA thrombolysis, n (\%) & $25(7.4)$ & $67(8.6)$ & 0.511 & $15(11.9)$ & 0.129 & $52(8.0)$ & 0.827 \\
\hline Initial NIHSS score (mean \pm SD) & $4.6(4.9)$ & $5.7(6.5)$ & 0.001 & $6.2(6.2)$ & 0.010 & $5.7(6.6)$ & 0.005 \\
\hline Initial NIHSS $\leq 1$ & $99(29.5)$ & $231(29.7)$ & 0.003 & $32(25.4)$ & 0.025 & $199(30.6)$ & 0.005 \\
\hline $2-3$ & $95(28.3)$ & $202(26.0)$ & & $32(25.4)$ & & $170(26.1)$ & \\
\hline $4-8$ & $88(26.2)$ & $150(19.3)$ & & $26(20.6)$ & & $124(19.0)$ & \\
\hline$\geq 9$ & $54(16.1)$ & $194(25.0)$ & & $36(28.6)$ & & $158(24.3)$ & \\
\hline Initial systolic BP (mean \pm SD) & $144.5 \pm 24.9$ & $142.0 \pm 23.6$ & 0.103 & $145.1(20.9)$ & 0.828 & $141.4 \pm 24.0$ & 0.054 \\
\hline \multicolumn{8}{|l|}{ Initial blood parameters (mean \pm SD) } \\
\hline Fasting glucose (mg/dL) & $121.5 \pm 52.3$ & $117.3 \pm 46.0$ & 0.222 & $119.4(63.8)$ & 0.728 & $116.9 \pm 41.7$ & 0.149 \\
\hline LDL - cholesterol (mg/dL) & $119.1 \pm 35.5$ & $115.2 \pm 36.5$ & 0.101 & $112.2(37.6)$ & 0.068 & $115.8 \pm 36.3$ & 0.174 \\
\hline WBC $\left(/ \mathrm{mm}^{3}\right)$ & $8,675.7 \pm 2784.7$ & $8,030.3 \pm 3052.8$ & 0.001 & 8,480.8 (3094.9) & 0.516 & $7,943.0 \pm 3029.3$ & $<0.001$ \\
\hline Hemoglobin (g/dL) & $14.5(1.8)$ & $13.3(1.8)$ & $<0.001$ & $14.0(1.9)$ & 0.004 & $13.2(1.8)$ & $<0.001$ \\
\hline
\end{tabular}

In these analysis, there were missing data for atrial fibrillation in 3 patients $(0.3 \%)$, smoking status in $4(0.36 \%)$, BMl in $33(3.0 \%)$, WBC in 1 (0.1\%), LDL-C in 22 (2.0\%), and fasting glucose in $98(8.8 \%)$ patients.

"current smokers vs. former smokers; ${ }^{\dagger}$ current smokers vs. never-smokers.

BMI, body mass index; BP, blood pressure; LDL, low density lipoprotein; NHHSS, National Institutes of Health Stroke Scale; tPA, tissue plasminogen activator; WBC, white blood cell.

(0.3\%), smoking status in 4 (0.36\%), BMI in $33(3.0 \%)$, WBC in $1(0.1 \%)$, LDL-C in $22(2.0 \%)$, and fasting glucose in 98 (8.8\%) patients.

The study participants included 336 current smokers (30.2\%), 126 former-smokers (11.3\%), and 651 never-smokers (58.5\%). Each group had significantly different baseline characteristics. Current smokers were mostly male and younger than formersmokers or never-smokers. Atrial fibrillation and cardioembolic stroke were significantly less frequent in current smokers than in former-smokers or never-smokers. Detailed comparisons of the baseline characteristics of the groups are presented in Table 1.

Smoking status was not significantly different between endpoint patients and those lost to follow-up. However, lost to follow-up patients had more severe strokes (higher mean initial NIHSS score) and had longer onset-to-admission times (Supplementary Table 1).

\section{Smoking status and initial stroke severity}

Initial mean NIHSS score was lower in current smokers than in former-smokers or never-smokers (Table 1). Figure 1 shows the frequency distribution of the quartiles of NIHSS scores in current smokers and non-smokers. Interestingly, the multivariate analysis revealed that current smoking was an independent predictor of severe stroke (defined as an NIHSS score of $\geq 4$, Table 2). When we defined severe stroke as an NIHSS score of $\geq 6$, current smoking remained as a significant predictor of severe stroke (Supplementary Table 2).

\section{Smoking status and functional outcomes}

The univariate analysis showed that current smoking status was more frequent among patients with a good functional outcome than in those with a poor outcome $(32.1 \%$ vs. $27.3 \%$, $P=0.082$ ). A good functional outcome was more common in current smokers than non-smokers: $64.0 \%(215 / 336)$ of cur- 


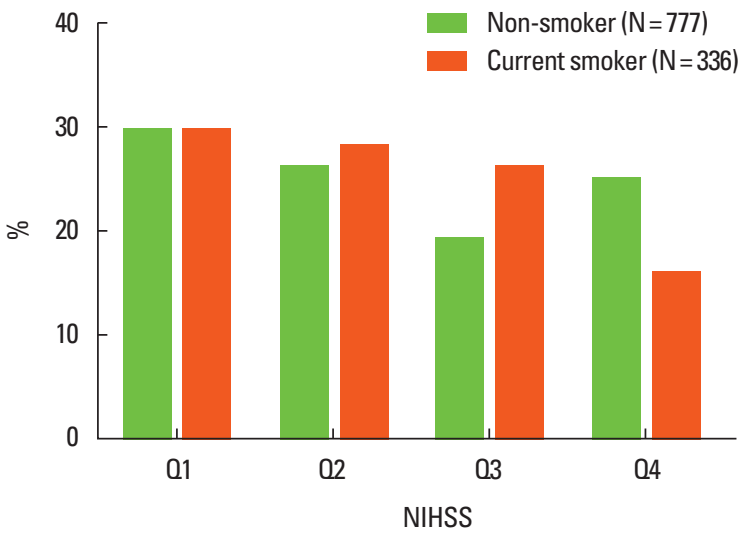

Figure 1. The frequency distribution of the quartiles of NIHSS scores in current smokers and in non-smokers.

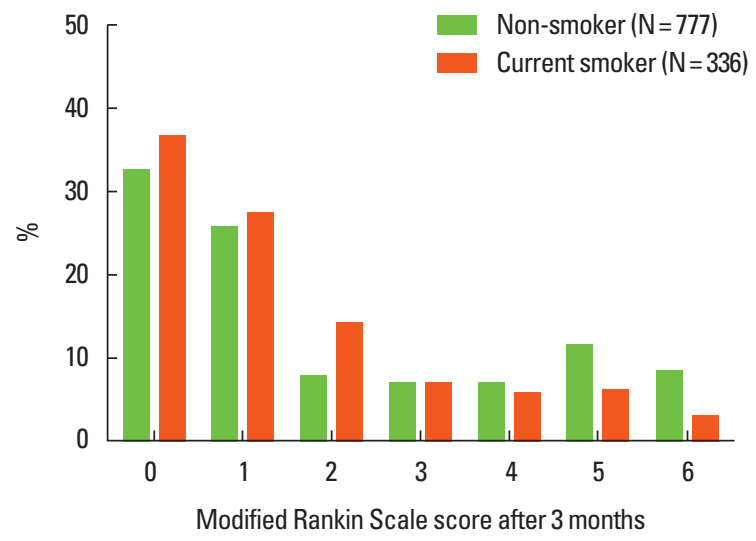

Figure 2. The frequencydistribution of mRS scores in current smokers and in non-smokers.

Table 2. Factors associated with severe stroke ( $\geq$ NIHSS 4) in the multivariate analysis

\begin{tabular}{|c|c|c|c|c|c|c|}
\hline \multirow{2}{*}{ Parameters } & \multicolumn{3}{|c|}{ Model 1} & \multicolumn{3}{|c|}{ Model 2} \\
\hline & Adjusted OR & $95 \% \mathrm{Cl}$ & $P$ value & Adjusted OR & $95 \% \mathrm{Cl}$ & $P$ value \\
\hline Onset-to-admission time, per 10 hours & 0.91 & 0.870 .95 & $<0.001$ & 0.91 & 0.870 .95 & $<0.001$ \\
\hline \multicolumn{7}{|l|}{ Demographics } \\
\hline Sex: males & 0.59 & 0.430 .83 & 0.002 & 0.51 & 0.350 .74 & $<0.001$ \\
\hline Age, per 10 years & 1.18 & 1.041 .35 & 0.009 & 1.18 & 1.041 .34 & 0.011 \\
\hline \multicolumn{7}{|l|}{ Body mass index $\left(\mathrm{kg} / \mathrm{m}^{2}\right)$} \\
\hline High BMI ( $\geq 25)$ & 0.63 & 0.450 .86 & 0.004 & 0.62 & 0.450 .86 & 0.004 \\
\hline Normal BMl & & & & ref. & & \\
\hline Low BMI $(<20)$ & 1.11 & 0.691 .78 & 0.680 & 1.09 & 0.681 .76 & 0.725 \\
\hline \multicolumn{7}{|l|}{ Smoking status } \\
\hline $\begin{array}{c}\text { Current smoker } \\
\text { Non-smoker }\end{array}$ & $\begin{array}{l}1.65 \\
\text { ref. }\end{array}$ & 1.152 .38 & 0.007 & & & \\
\hline Current smoker & & & & 1.65 & 0.972 .82 & 0.001 \\
\hline Former smoker & & & & 1.92 & 1.282 .87 & 0.065 \\
\hline Never-smoker & & & & ref. & & \\
\hline \multicolumn{7}{|l|}{ Vascular risk factors } \\
\hline Hypertension & 1.12 & 0.821 .52 & 0.487 & 1.10 & 0.811 .50 & 0.532 \\
\hline Diabetes mellitus & 1.54 & 1.122 .11 & 0.007 & 1.56 & 1.132 .13 & 0.006 \\
\hline Hyperlipidemia & 0.97 & 0.711 .33 & 0.852 & 0.96 & 0.701 .32 & 0.802 \\
\hline Atrial fibrillation & 1.90 & 1.003 .63 & 0.051 & 1.93 & 1.013 .70 & 0.046 \\
\hline \multicolumn{7}{|l|}{ Stroke subtype } \\
\hline Small vessel disease & & & & ref. & & \\
\hline Large artery disease & 2.20 & 1.573 .06 & $<0.001$ & 2.18 & 1.563 .05 & $<0.001$ \\
\hline Cardioembolism & 2.35 & 1.284 .31 & 0.006 & 2.38 & 1.304 .36 & 0.005 \\
\hline
\end{tabular}

In Model 1, current smokers were compared with non-smokers. In Model 2, current smokers and former smokers were compared with never-smokers. NIHSS, National Institutes of Health Stroke Scale; BMI, body mass index.

rent smokers and $58.4 \%(454 / 777)$ of non-smokers $(57.9 \%$ [73/126] of former-smokers and $58.5 \%[381 / 651]$ of neversmokers) had a good functional outcome. However, these differences were not statistically significant. Figure 2 shows the frequency distribution of the mRS scores in current smokers and non-smokers.

The percentage of smokers was lower among the patients who died within three months compared with that in the survivor group ( $13.3 \%$ vs. $31.4 \%, P=0.001)$. In particular, 3-month mor- tality was higher in non-smokers than in current smokers: $8.4 \%$ $(65 / 777)$ vs. $3.0 \%(10 / 336)$.

Other parameters, including age, sex, BMI, vascular risk factors, initial NIHSS score, stroke subtype, onset-to-admission time, tPA therapy, mean value of initial systolic BP, and blood parameters were primarily associated with patients' outcomes. The results of the univariate analysis are described in Supplementary Tables 3 and 4.

In the multivariate analysis, smoking status was not associat- 
Table 3. Factors associated with poor functional outcome (MRS 2-6) in the multivariate analysis

\begin{tabular}{|c|c|c|c|c|c|c|c|c|}
\hline \multirow{3}{*}{$\begin{array}{l}\text { Parameters } \\
\text { Onset-to-admission time, per } 10 \text { hours }\end{array}$} & \multicolumn{4}{|c|}{ Model 1} & \multicolumn{4}{|c|}{ Model 2} \\
\hline & \multirow{2}{*}{$\begin{array}{c}\text { Adjusted OR } \\
0.98\end{array}$} & \multicolumn{2}{|c|}{$95 \% \mathrm{Cl}$} & \multirow{2}{*}{$\begin{array}{c}P \text { value } \\
0.390\end{array}$} & \multirow{2}{*}{$\begin{array}{c}\text { Adjusted } \\
0.98\end{array}$} & \multicolumn{2}{|c|}{$95 \% \mathrm{Cl}$} & \multirow{2}{*}{$\begin{array}{c}\text { Pvalue } \\
0.409\end{array}$} \\
\hline & & 0.93 & 1.03 & & & 0.93 & 1.03 & \\
\hline \multicolumn{9}{|l|}{ Demographics } \\
\hline Sex: males & 0.66 & 0.43 & 1.00 & 0.052 & 0.58 & 0.37 & 0.93 & 0.024 \\
\hline Age, per 10 years & 1.17 & 1.01 & 1.37 & 0.041 & 1.17 & 1.00 & 1.36 & 0.046 \\
\hline \multicolumn{9}{|l|}{ Body mass index $\left(\mathrm{kg} / \mathrm{m}^{2}\right)$} \\
\hline High BMI ( $\geq 25$ ) & 0.66 & 0.45 & 0.97 & 0.036 & 0.66 & 0.45 & 0.97 & 0.033 \\
\hline Normal BMI & ref. & & & & ref. & & & \\
\hline Low BMI (<20) & 0.81 & 0.45 & 1.43 & 0.461 & 0.80 & 0.45 & 1.42 & 0.440 \\
\hline \multicolumn{9}{|l|}{ Smoking status } \\
\hline $\begin{array}{c}\text { Current smoker } \\
\text { Non-smoker }\end{array}$ & $\begin{array}{l}1.36 \\
\text { ref. }\end{array}$ & 0.88 & 2.11 & 0.168 & & & & \\
\hline Current smoker & & & & & 1.53 & 0.95 & 2.48 & 0.083 \\
\hline Former smoker & & & & & 1.48 & 0.78 & 2.82 & 0.234 \\
\hline Never-smoker & & & & & ref. & & & \\
\hline \multicolumn{9}{|l|}{ Vascular risk factors } \\
\hline Hypertension & 0.88 & 0.61 & 1.29 & 0.515 & 0.88 & 0.60 & 1.28 & 0.494 \\
\hline Diabetes mellitus & 0.90 & 0.59 & 1.38 & 0.622 & 0.90 & 0.59 & 1.38 & 0.638 \\
\hline Hyperlipidemia & 0.68 & 0.46 & 1.02 & 0.062 & 0.68 & 0.45 & 1.02 & 0.060 \\
\hline Atrial fibrillation & 0.82 & 0.36 & 1.83 & 0.620 & 0.82 & 0.37 & 1.84 & 0.632 \\
\hline Initial NIHSS $\leq 1$ & ref. & & & & ref. & & & \\
\hline $2-3$ & 1.54 & 0.95 & 2.50 & 0.081 & 1.53 & 0.94 & 2.48 & 0.088 \\
\hline $4-8$ & 4.86 & 2.98 & 7.94 & $<0.001$ & 4.80 & 2.93 & 7.84 & $<0.001$ \\
\hline$\geq 9$ & 16.66 & 8.98 & 30.93 & $<0.001$ & 16.46 & 8.86 & 30.57 & $<0.001$ \\
\hline \multicolumn{9}{|l|}{ Stroke subtype } \\
\hline Small vessel disease & ref. & & & ref. & ref. & & & \\
\hline Large artery disease & 1.79 & 1.19 & 2.69 & 0.005 & 1.78 & 1.18 & 2.68 & 0.006 \\
\hline Cardioembolism & 1.85 & 0.86 & 3.98 & 0.113 & 1.88 & 0.87 & 4.03 & 0.106 \\
\hline Received tPA thrombolysis & 0.39 & 0.20 & 0.76 & 0.006 & 0.39 & 0.20 & 0.76 & 0.006 \\
\hline Initial systolic BP, per 10 mmHg & 1.04 & 0.97 & 1.12 & 0.284 & 1.04 & 0.96 & 1.12 & 0.303 \\
\hline \multicolumn{9}{|l|}{ Initial blood parameters } \\
\hline Fasting glucose, per $10 \mathrm{mg} / \mathrm{dL}$ & 1.05 & 1.00 & 1.09 & 0.034 & 1.05 & 1.00 & 1.09 & 0.032 \\
\hline LDL-cholesterol, per $10 \mathrm{mg} / \mathrm{dL}$ & 1.02 & 0.97 & 1.07 & 0.476 & 1.02 & 0.97 & 1.07 & 0.490 \\
\hline WBC, per $1,000 / \mathrm{mm}^{3}$ & 1.05 & 0.98 & 1.11 & 0.152 & 1.05 & 0.98 & 1.11 & 0.157 \\
\hline Hemoglobin, per $1 \mathrm{~g} / \mathrm{dL}$ & 0.98 & 0.88 & 1.09 & 0.667 & 0.98 & 0.88 & 1.09 & 0.688 \\
\hline
\end{tabular}

In Model 1, current smokers were compared with non-smokers. In Model 2, current smokers and former smokers were compared with never-smokers. All variables in the univariate analysis were included in the multivariate analysis.

BMI, body mass index; BP, blood pressure; LDL, low density lipoprotein; NIHSS, National Institutes of Health Stroke Scale; tPA, tissue plasminogen activator; WBC, white blood cell.

ed with functional outcome and death. Age, initial high stroke severity, large artery disease, high fasting blood glucose, and WBC count were independent prognostic factors for a poor outcome. Male gender, high BMI, and tPA therapy were good prognostic factors (Tables 3 and 4).

\section{Effect of smoking status in the subgroups}

In most subgroups, the functional outcome was not significantly different between current smokers and non-smokers (Figure 3 and Supplementary Table 5); however, current smoking was associated with a poor functional outcome in patients treated with tPA therapy and with a low BMI $(P=0.036$ and $P=0.031$, respectively; Supplemental Table 5).

\section{Discussion}

The baseline characteristics of patients experiencing acute ischemic stroke were significantly different according to smoking status. Current smokers were predominantly young and male with a relatively benign baseline. A history of hypertension and atrial fibrillation were less frequent when compared with non-smokers. In addition, initial stroke severity was milder in current smokers. However, after adjustment for confounding variables, current smoking was independently associated with severe stroke. In the univariate analyses revealed that smokers displayed a good functional outcome and significantly less mortality within three months when compared with non-smokers; 
Table 4. Factors associated with 3-month death in the multivariate analysis

\begin{tabular}{|c|c|c|c|c|c|c|c|c|}
\hline \multirow{3}{*}{$\begin{array}{l}\text { Parameters } \\
\text { Onset-to-admission time, per } 10 \text { hours }\end{array}$} & \multicolumn{4}{|c|}{ Model 1} & \multicolumn{4}{|c|}{ Model 2} \\
\hline & \multirow{2}{*}{$\begin{array}{c}\text { Adjusted OR } \\
0.86\end{array}$} & \multicolumn{2}{|c|}{$95 \% \mathrm{Cl}$} & \multirow{2}{*}{$\begin{array}{c}P \text { value } \\
0.109\end{array}$} & \multirow{2}{*}{$\begin{array}{c}\text { Adjusted OR } \\
0.85\end{array}$} & \multicolumn{2}{|c|}{$95 \% \mathrm{Cl}$} & \multirow{2}{*}{$\begin{array}{l}\text { Pvalue } \\
0.107\end{array}$} \\
\hline & & 0.71 & 1.03 & & & 0.71 & 1.03 & \\
\hline \multicolumn{9}{|l|}{ Demographics } \\
\hline Sex: males & 1.19 & 0.48 & 2.95 & 0.710 & 0.94 & 0.33 & 2.66 & 0.906 \\
\hline Age, per 10 years & 2.72 & 1.71 & 4.33 & 0.000 & 2.74 & 1.71 & 4.38 & 0.000 \\
\hline \multicolumn{9}{|l|}{ Body mass index $\left(\mathrm{kg} / \mathrm{m}^{2}\right)$} \\
\hline High BMI ( $\geq 25)$ & 1.09 & 0.42 & 2.85 & 0.859 & 1.07 & 0.41 & 2.82 & 0.884 \\
\hline Normal BMI & ref. & & & & ref. & & & \\
\hline Low BMI (<20) & 0.50 & 0.15 & 1.66 & 0.256 & 0.46 & 0.14 & 1.56 & 0.213 \\
\hline \multicolumn{9}{|l|}{ Smoking status } \\
\hline $\begin{array}{c}\text { Current smoker } \\
\text { Non-smoker }\end{array}$ & $\begin{array}{l}1.34 \\
\text { ref. }\end{array}$ & 0.41 & 4.34 & 0.627 & & & & \\
\hline Current smoker & & & & & 1.73 & 0.47 & 6.34 & 0.411 \\
\hline Former smoker & & & & & 1.88 & 0.53 & 6.75 & 0.330 \\
\hline Never-smoker & & & & & ref. & & & \\
\hline \multicolumn{9}{|l|}{ Vascular risk factors } \\
\hline Hypertension & 0.80 & 0.32 & 1.99 & 0.628 & 0.77 & 0.31 & 1.93 & 0.575 \\
\hline Diabetes mellitus & 0.46 & 0.17 & 1.24 & 0.124 & 0.50 & 0.18 & 1.36 & 0.175 \\
\hline Hyperlipidemia & 0.54 & 0.17 & 1.64 & 0.273 & 0.51 & 0.16 & 1.59 & 0.247 \\
\hline Atrial fibrillation & 0.47 & 0.08 & 2.79 & 0.405 & 0.46 & 0.07 & 2.77 & 0.393 \\
\hline Initial NIHSS $\leq 1$ & ref. & & & & ref. & & & \\
\hline $2-3$ & 3.58 & 0.33 & 38.80 & 0.294 & 3.60 & 0.33 & 39.33 & 0.293 \\
\hline $4-8$ & 4.86 & 0.49 & 48.08 & 0.176 & 4.87 & 0.49 & 48.49 & 0.177 \\
\hline$\geq 9$ & 17.87 & 2.07 & 154.18 & 0.009 & 17.87 & 2.05 & 155.64 & 0.009 \\
\hline \multicolumn{9}{|l|}{ Stroke subtype } \\
\hline Small vessel disease & ref. & & & & ref. & & & \\
\hline Large artery disease & 1.78 & 0.40 & 7.98 & 0.448 & 1.71 & 0.38 & 7.73 & 0.484 \\
\hline Cardioembolism & 4.02 & 0.46 & 35.60 & 0.211 & 4.20 & 0.47 & 37.63 & 0.199 \\
\hline Received tPA thrombolysis & 0.80 & 0.26 & 2.45 & 0.698 & 0.80 & 0.26 & 2.47 & 0.703 \\
\hline Initial systolic BP, per $10 \mathrm{mmHg}$ & 1.08 & 0.92 & 1.26 & 0.354 & 1.07 & 0.91 & 1.26 & 0.410 \\
\hline \multicolumn{9}{|l|}{ Initial blood parameters } \\
\hline Fasting glucose, per $10 \mathrm{mg} / \mathrm{dL}$ & 1.10 & 1.02 & 1.17 & 0.010 & 1.09 & 1.02 & 1.17 & 0.016 \\
\hline LDL-cholesterol, per $10 \mathrm{mg} / \mathrm{dL}$ & 1.11 & 0.98 & 1.25 & 0.109 & 1.10 & 0.98 & 1.25 & 0.113 \\
\hline WBC, per $1,000 / \mathrm{mm}^{3}$ & 1.16 & 1.03 & 1.30 & 0.014 & 1.15 & 1.02 & 1.30 & 0.018 \\
\hline Hemoglobin, per $1 \mathrm{~g} / \mathrm{dL}$ & 0.81 & 0.66 & 1.01 & 0.057 & 0.82 & 0.66 & 1.01 & 0.062 \\
\hline
\end{tabular}

In Model 1, current smokers were compared with non-smokers. In Model 2, current smokers and former smokers were compared with never-smokers. All variables in the univariate analysis were included in the multivariate analysis.

BMI, body mass index; BP, blood pressure; LDL, low density lipoprotein; NIHSS, National Institutes of Health Stroke Scale; tPA, tissue plasminogen activator; WBC, white blood cell.

however, smoking status was not independently related with functional outcome after adjustment for demographics and other prognostic indicators. These results were consistent in subgroups that were stratified by gender and stroke subtype.

The baseline profile of smokers in our study corresponded well to the results from previous studies. ${ }^{6,8-10,12-14,17}$ The younger mean age in smokers may be associated with smokers having strokes at an earlier age than non-smokers. Cigarette smoking is known to be an independent risk factor for atrial fibrillation and hypertension. ${ }^{18,19}$ However, as with previous studies, ${ }^{6,8-10,12,14,17}$ our research reported a lower prevalence of atrial fibrillation and hypertension in current smokers with acute ischemic stroke when compared with non-smokers. Our univariate analysis showed a milder stroke severity in current smokers compared with non-smokers. This might be attributed to the lower frequency of atrial fibrillation (thereby low prevalence of cardioembolic stroke) in current smokers than that in non-smokers. These counterintuitive findings can be partially explained by a selective survival bias and demographic differences; atrial fibrillation and hypertension may be less frequent in current smokers because they are approximately 10 years younger than non-smokers in our study. In addition, patients with vascular risk factors may be less inclined to smoke as they have encountered non-smoking education or counseling more often. Other unmeasured confounding factors may be involved in different baseline characteristics that are related to smoking status. Other unidentified health problems may 


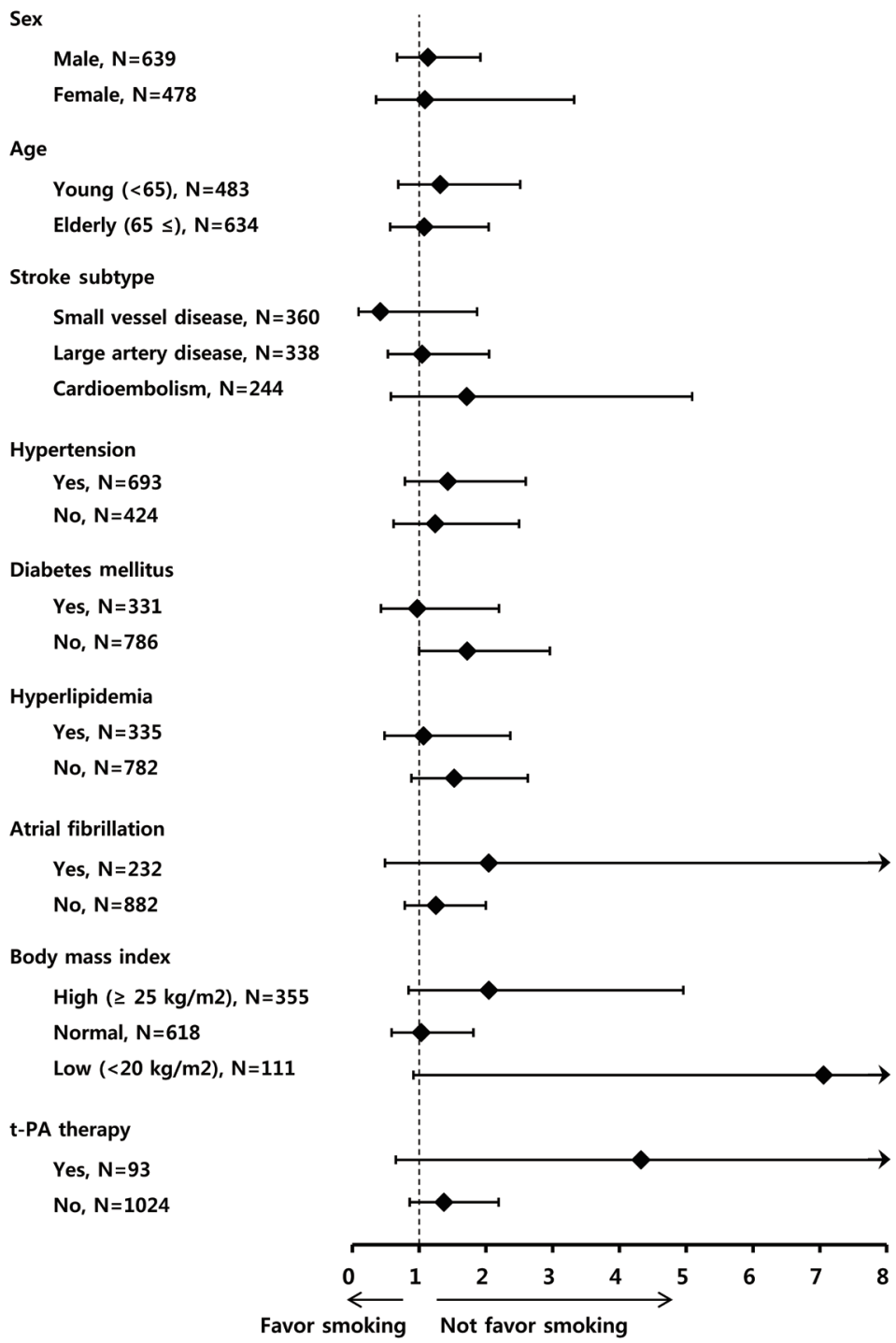

Figure 3. The effect of current smoking on functional outcome in different subgroups (current smoker versus non-smoker). The diamond represents the point estimate of the adjusted odds ratio and the horizontal line represents the 95 percent confidence intervals. Poor functional outcome was defined as modified Rankin Scale score of $\geq 2$, measured at three months after stroke. All variables in the main analysis were included as confounders in this subgroup analysis.

exist that are underlying drivers of non-smoking behavior. It is a more reasonable hypothesis that health-related behavior modification or health-seeking behavior is driving these findings rather than the presence of a protective effect of smoking.

The variables that are known to be potential prognostic factors required careful statistical analysis as there was a wide discrepancy between the baseline characteristics of the different groups. In both our study and the literature, there are some important limitations in performing this task; despite including a considerable number of well-known prognostic factors in the multivariable analysis, unmeasured confounding variables may contribute to erroneous conclusions. We believe that the utility of using smoking as a prognostic tool is controversial as it may be largely attributed to unaccounted confounding variables.
Socioeconomic status is likely to be an important confounder that has not been measured in this study. Low socioeconomic status may be a predictor of poor outcome after stroke. ${ }^{20}$ Most previous studies have not included socioeconomic status in multivariable analyses. ${ }^{7-17} \mathrm{Kim}$ et al. ${ }^{6}$ included socioeconomic status when analyzing the effect of baseline smoking status on the long-term risk of a poor outcome (first vascular event or death) in stroke patients. Although the univariate analysis showed that smokers have a better outcome than people who have never smoked $(P=0.03)$, they had a greater risk of a poor outcome in the multivariate analysis $(P=0.003)$. In addition, changes in smoking habits after the index stroke may affect stroke outcome. These were not evaluated in our research or previous studies. ${ }^{6-13,15-17}$ Although little is known about the effects of smoking cessation on short-term 
stroke recovery, smoking cessation as a long-term protective measure with respect to mortality and cardiovascular events is well defined. ${ }^{21,22}$ Current smokers with mild or no disability may continue smoking compared with those who experienced severe stroke, ${ }^{23}$ which may affect the functional outcome. Moreover, smoking habits can be affected by previous stroke or functional status, which may be an important confounding factor. ${ }^{15,23}$ In previous studies, smokers are less likely to report a history of prior strokes than non-smokers ( $20.6 \%$ vs. $33.8 \%) ;{ }^{15}$ therefore, we only included patients with first-ever stroke and no functional disability to exclude their confounding effects. However, many previous studies did not exclude or adjust for these factors in the multivariate analysis. ${ }^{7,8,10,12,13,16,17}$

Two previous studies have shown that patients with thrombolytic therapy experience a paradoxical short-term benefit of smoking. ${ }^{16,17}$ Smoking was associated with either improved recanalization ${ }^{16}$ or short-term improvement of stroke severity. ${ }^{17}$ The authors of these studies have hypothesized that smokers may have thrombi with more dissoluble characteristics. Nevertheless, smoking status was not associated with the functional outcome at three months. No association between baseline smoking status and functional outcome is reproduced in other studies. ${ }^{9,12}$ In these studies, despite an association with good outcomes in descriptive or univariate analyses, current smoking was not independently associated with the functional outcome after adjusting for confounding variables. In our subgroup analysis, smokers with thrombolytic therapy tended to have a poorer outcome than nonsmokers; however, the false positive rates associated with the application of multiple statistical tests may be high; the probability of one or more false positive findings when 9 subgroup tests are performed is about 40 percent. ${ }^{24}$ Despite this limitation, our finding suggested that smoking might not predict improved functional outcome after thrombolytic therapy, irrespective of a reported high recanalization rate. ${ }^{16}$

A previous study has discussed the differing prognostic effect of smoking in relation to stroke subtypes: smoking is found to be beneficial only in atherosclerotic stroke. ${ }^{15}$ In contrast, another study has shown that male smokers with acute atherosclerotic stroke have an increased risk of a poor 90-day functional outcome, independent of other variables. ${ }^{7}$ Smoking was not independently associated with the functional outcome in atherosclerotic stroke in our subgroup analysis. The effect of smoking on functional outcome according to stroke subtypes needs to be further studied.

Our study has limitations. First, there may be a selection bias as patients lost to follow-up were excluded. These patients may have a poor functional outcome; in our data, this group had greater initial stroke severity and higher glucose levels (Supplementary Ta- ble 1), which are well known poor prognostic factors. Nevertheless, smoking status between the included and excluded (patients lost to follow-up) patients were not significantly different in our study (Supplementary Table 1); therefore, excluding these data would not significantly affect our study findings. Second, similar to many previous studies, it was not possible to analyze the dose effect of smoking because detailed information about quantity and potency was not available. Moreover, given that the risk of cardiovascular events increases with the number of cigarettes smoked, the impact of smoking on stroke outcome is likely to differ between light and heavy smokers. ${ }^{1,2,25}$ This effect needs to be explored in more detail. Third, there were some missing data in our study, in particular the fasting blood glucose levels and body mass index. These omissions were random because most baseline characteristics, such as smoking status and initial stroke severity were not different relative to the presence of blood parameters (Supplementary Table 6). Fourth, although we included only patients without prior stroke or functional disability, smokers are likely to have other medical problems, such as coronary artery and pulmonary disease. These medical problems may contribute to the functional outcome after stroke. Unfortunately, we were not able to adjust for these potential confounding factors.

\section{Conclusions}

In this study, smoking was not associated with a good functional outcome. This does not support the paradoxical benefit of smoking on functional outcome following acute ischemic stroke, which might be attributed to unmeasured confounding variables.

\section{Acknowledgments}

We thank Dr. Sean HaShemi (Department of Otolaryngology, Head and Neck Surgery, Boston University Medical Center, 820 Harrison Blvd, FGH 4th Floor, Boston, MA USA 02118, email: Sean.Hashemi@bu.edu) for helping us prepare this manuscript.

\section{References}

1. Kondo T, Osugi S, Shimokata K, Honjo H, Morita Y, Maeda K, et al. Smoking and smoking cessation in relation to all-cause mortality and cardiovascular events in 25,464 healthy male Japanese workers. Circ J 2011;75:2885-2892.

2. Wolf PA, D’Agostino RB, Kannel WB, Bonita R, Belanger AJ. Cigarette smoking as a risk factor for stroke. The Framingham Study. JAMA 1988;259:1025-1029.

3. Go AS, Mozaffarian D, Roger VL, Benjamin EJ, Berry JD, Bor- 
den WB, et al. Heart disease and stroke statistics--2013 update: a report from the American Heart Association. Circulation 2013; 127:e6-e245.

4. Hong KS, Bang OY, Kang DW, Yu KH, Bae HJ, Lee JS, et al. Stroke statistics in Korea: part I. Epidemiology and risk factors: a report from the korean stroke society and clinical research center for stroke. J Stroke 2013;15:2-20.

5. Park TH, Kim MK, Lee KB, Park JM, Lee SJ, Jung KH, et al. Population Attributable Risk of Major Risk Factors for Ischemic Stroke in the Korean Population. Korean J Stroke 2008; 10:125-133.

6. Kim J, Gall SL, Dewey HM, Macdonell RA, Sturm JW, Thrift AG. Baseline smoking status and the long-term risk of death or nonfatal vascular event in people with stroke: a 10-year survival analysis. Stroke 2012;43:3173-3178.

7. Kumagai N, Okuhara Y, Iiyama T, Fujimoto Y, Takekawa H, Origasa $\mathrm{H}$, et al. Effects of smoking on outcomes after acute atherothrombotic stroke in Japanese men. J Neurol Sci 2013; 335:164-168.

8. Ovbiagele B, Weir CJ, Saver JL, Muir KW, Lees KR. Effect of smoking status on outcome after acute ischemic stroke. Cerebrovasc Dis 2006;21:260-265.

9. Aries MJ, Uyttenboogaart M, Koch MW, Langedijk M, Vroomen PC, Luijckx GJ, et al. Does smoking influence outcome after intravenous thrombolysis for acute ischaemic stroke? Eur J Neurol 2009;16:819-822.

10. Edjoc RK, Reid RD, Sharma M, Fang J, Registry of the Canadian Stroke N. The prognostic effect of cigarette smoking on stroke severity, disability, length of stay in hospital, and mortality in a cohort with cerebrovascular disease. J Stroke Cerebrovasc Dis 2013;22:e446-454.

11. Fekete K, Szatmari S, Szocs I, Szekeres C, Szasz J, Mihalka L, et al. Prestroke alcohol consumption and smoking are not associated with stroke severity, disability at discharge, and case fatality. J Stroke Cerebrovasc Dis 2014;23:e31-37.

12. Moulin S, Padjen-Bogosavljevic V, Marichal A, Cordonnier C, Jovanovic DR, Gautier S, et al. Influence of differences in case mix on the better outcome of smokers after intravenous thrombolysis for acute cerebral ischemia. Eur Neurol 2012;67:178-183. 13. Weng WC, Huang WY, Chien YY, Wu CL, Su FC, Hsu HJ, et al. The impact of smoking on the severity of acute ischemic stroke. J Neurol Sci 2011;308:94-97.

14. Ali SF, Smith EE, Bhatt DL, Fonarow GC, Schwamm LH. Paradoxical association of smoking with in-hospital mortality among patients admitted with acute ischemic stroke. J Am Heart Assoc 2013;2:e00171.

15. Bang OY, Park HY, Lee PH, Kim GM, Chung CS, Lee KH. Improved outcome after atherosclerotic stroke in male smoker. J Neurol Sci 2007;260:43-48.

16. Kufner A, Nolte CH, Galinovic I, Brunecker P, Kufner GM, Endres $\mathrm{M}$, et al. Smoking-thrombolysis paradox: recanalization and reperfusion rates after intravenous tissue plasminogen activator in smokers with ischemic stroke. Stroke 2013;44:407-413.

17. Ovbiagele B, Saver JL. The smoking-thrombolysis paradox and acute ischemic stroke. Neurology 2005;65:293-295.

18. Bowman TS, Gaziano JM, Buring JE, Sesso HD. A prospective study of cigarette smoking and risk of incident hypertension in women. J Am Coll Cardiol 2007;50:2085-2092.

19. Heeringa J, Kors JA, Hofman A, van Rooij FJ, Witteman JC. Cigarette smoking and risk of atrial fibrillation: the Rotterdam Study. Am Heart J 2008;156:1163-1169.

20. Addo J, Ayerbe L, Mohan KM, Crichton S, Sheldenkar A, Chen $\mathrm{R}$, et al. Socioeconomic status and stroke: an updated review. Stroke 2012;43:1186-1191.

21. Gellert C, Schottker B, Muller H, Holleczek B, Brenner H. Impact of smoking and quitting on cardiovascular outcomes and risk advancement periods among older adults. Eur J Epidemiol 2013;28:649-658.

22. Wannamethee SG, Shaper AG, Whincup PH, Walker M. Smoking cessation and the risk of stroke in middle-aged men. JAMA 1995;274:155-160.

23. Bak S, Sindrup SH, Alslev T, Kristensen O, Christensen K, Gaist D. Cessation of smoking after first-ever stroke: a follow-up study. Stroke 2002;33:2263-2269.

24. Lagakos SW. The challenge of subgroup analyses--reporting without distorting. N Engl J Med 2006;354:1667-1669.

25. Jacobs DR, Jr., Adachi H, Mulder I, Kromhout D, Menotti A, Nissinen A, et al. Cigarette smoking and mortality risk: twentyfive-year follow-up of the Seven Countries Study. Arch Intern Med 1999;159:733-740. 
Supplementary Table 1. Baseline characteristics of patients lost to follow-up

\begin{tabular}{|c|c|c|c|}
\hline Parameters & Included $n=1,117$ & Follow-up loss $n=131$ & $P$ value \\
\hline Onset-to-admission time (hour), (mean \pm SD) & $28.6(37.1)$ & $38.2(44.0)$ & 0.017 \\
\hline Males, n (\%) & $639(57.2)$ & $82(62.6)$ & 0.237 \\
\hline Age (mean \pm SD) & $65.3(13.5)$ & $66.6(15.0)$ & 0.322 \\
\hline Body mass index $\left(\mathrm{kg} / \mathrm{m}^{2}\right)$, (mean $\left.\pm \mathrm{SD}\right)$ & $3.2(0.1)$ & $3.2(0.3)$ & 0.374 \\
\hline High BMI ( $\geq 25)$, n (\%) & $37(29.8)$ & $355(32.7)$ & 0.756 \\
\hline Normal BMI, $\mathrm{n}(\%)$ & $75(60.5)$ & $618(57.0)$ & \\
\hline Low BMI (<20), n (\%) & $111(10.2)$ & $12(9.7)$ & \\
\hline \multicolumn{4}{|l|}{ Smoking status, $\mathrm{n}(\%)$} \\
\hline Current smoker & $336(30.2)$ & $34(26.4)$ & 0.368 \\
\hline Non-smoker & $777(69.3)$ & $95(73.6)$ & \\
\hline Former smoker & $126(11.3)$ & $16(12.4)$ & \\
\hline Never-smoker & $651(58.5)$ & 79 (61.2) & \\
\hline Hypertension, $n(\%)$ & $693(62.0)$ & $79(60.3)$ & 0.699 \\
\hline Diabetes Mellitus, $n(\%)$ & $331(29.6)$ & $45(34.4)$ & 0.265 \\
\hline Hyperlipidemia, n (\%) & $335(30.0)$ & $38(29.0)$ & 0.816 \\
\hline Atrial fibrillation, $\mathrm{n}(\%)$ & $232(20.8)$ & $23(17.7)$ & 0.402 \\
\hline \multicolumn{4}{|l|}{ Stroke subtype, n (\%) } \\
\hline Large artery disease & $338(30.3)$ & $49(37.4)$ & 0.061 \\
\hline Small vessel disease & 360 (32.2) & $32(24.4)$ & \\
\hline Cardioembolism & $244(21.8)$ & $27(20.6)$ & \\
\hline \multicolumn{4}{|l|}{ Undetermined } \\
\hline Incomplete & $10(0.9)$ & $4(3.1)$ & \\
\hline 2 or more & $41(3.7)$ & $2(1.5)$ & \\
\hline Negative & $58(5.2)$ & $10(7.6)$ & \\
\hline Other determined & $66(5.9)$ & $7(5.3)$ & \\
\hline Received tPA thrombolysis, $\mathrm{n}(\%)$ & $93(8.3)$ & $15(11.5)$ & 0.229 \\
\hline Initial NIHSS score (mean \pm SD) & $5.4(6.1)$ & $6.9(6.7)$ & 0.015 \\
\hline Initial NIHSS $\leq 1$ & $331(29.6)$ & $32(24.4)$ & 0.004 \\
\hline $2-3$ & $297(26.6)$ & $24(18.3)$ & \\
\hline $4-8$ & $239(21.4)$ & $28(21.4)$ & \\
\hline$\geq 9$ & $250(22.4)$ & $47(35.9)$ & \\
\hline Initial systolic BP (mean $\pm S D)$ & $142.8(24.0)$ & $140.5(27.0)$ & 0.304 \\
\hline \multicolumn{4}{|l|}{ Initial blood parameters (mean \pm SD) } \\
\hline Fasting glucose (mg/dL) & $118.6(47.9)$ & $128.9(59.7)$ & 0.071 \\
\hline $\mathrm{LDL}$ - cholesterol (mg/dL) & $116.4(36.3)$ & $114.2(35.2)$ & 0.505 \\
\hline WBC $\left(/ \mathrm{mm}^{3}\right)$ & $8,231(2987)$ & $8,497(2946)$ & 0.335 \\
\hline Hemoglobin (g/dL) & $13.7(1.9)$ & $13.5(2.0)$ & 0.271 \\
\hline
\end{tabular}

In these analysis, there were missing data for atrial fibrillation in $4(0.3 \%)$, smoking in $6(0.5 \%)$, BMl in $40(3.2 \%)$, WBC in one (0.1\%), LDL-cholesterol in 26 (2.1\%), and fasting blood glucose in $109(8.7 \%)$ patients.

BMI, body mass index; BP, blood pressure; LDL, low density lipoprotein; NIHSS, National Institutes of Health Stroke Scale; tPA, tissue plasminogen activator; WBC, white blood cell. 
Supplementary Table 2. Factors associated with severe stroke ( $\geq$ NIHSS 6) in the multivariate analysis

\begin{tabular}{|c|c|c|c|c|c|c|c|}
\hline \multirow{3}{*}{$\begin{array}{l}\text { Parameters } \\
\text { Onset-to-admission time, per } 10 \text { hours }\end{array}$} & \multicolumn{4}{|c|}{ Model 1} & \multicolumn{3}{|c|}{ Model 2} \\
\hline & \multirow{2}{*}{$\begin{array}{c}\text { Adjusted OR } \\
0.84\end{array}$} & \multicolumn{2}{|c|}{$95 \% \mathrm{Cl}$} & \multirow{2}{*}{$\begin{array}{l}P \text { value } \\
<0.001\end{array}$} & \multirow{2}{*}{$\begin{array}{c}\text { Adjusted OR } \\
0.84\end{array}$} & \multirow{2}{*}{$\begin{array}{c}95 \% \mathrm{Cl} \\
0.790 .89\end{array}$} & \multirow{2}{*}{$\begin{array}{l}\text { Pvalue } \\
<0.001\end{array}$} \\
\hline & & 0.79 & 0.89 & & & & \\
\hline \multicolumn{8}{|l|}{ Demographics } \\
\hline Sex:males & 0.68 & 0.47 & 1.00 & 0.050 & 0.60 & 0.390 .92 & 0.019 \\
\hline Age, per 10 years & 1.22 & 1.06 & 1.42 & 0.007 & 1.22 & 1.051 .41 & 0.009 \\
\hline \multicolumn{8}{|l|}{ Body mass index $\left(\mathrm{kg} / \mathrm{m}^{2}\right)$} \\
\hline High BMI ( $\geq 25$ ) & 0.44 & 0.29 & 0.64 & $<0.001$ & 0.43 & 0.290 .64 & $<0.001$ \\
\hline Normal BMl & ref. & & & & ref. & & \\
\hline Low BMI (<20) & 0.85 & 0.51 & 1.42 & 0.525 & 0.83 & 0.501 .39 & 0.483 \\
\hline \multicolumn{8}{|l|}{ Smoking status } \\
\hline $\begin{array}{c}\text { Current smoker } \\
\text { Non-smoker }\end{array}$ & $\begin{array}{r}1.57 \\
\text { ref. }\end{array}$ & 1.03 & 2.39 & 0.037 & & & \\
\hline Current smoker & & & & & 1.78 & 1.122 .83 & 0.014 \\
\hline Former smoker & & & & & 1.53 & 0.842 .80 & 0.167 \\
\hline Never-smoker & & & & & ref. & & \\
\hline \multicolumn{8}{|l|}{ Vascular risk factors } \\
\hline Hypertension & 0.97 & 0.68 & 1.38 & 0.863 & 0.95 & 0.671 .37 & 0.800 \\
\hline Diabetes mellitus & 1.13 & 0.79 & 1.63 & 0.497 & 1.15 & 0.801 .65 & 0.457 \\
\hline Hyperlipidemia & 1.23 & 0.85 & 1.78 & 0.270 & 1.22 & 0.841 .77 & 0.289 \\
\hline Atrial fibrillation & 2.16 & 1.08 & 4.32 & 0.029 & 2.19 & 1.094 .38 & 0.027 \\
\hline \multicolumn{8}{|l|}{ Stroke subtype } \\
\hline Small vessel disease & ref. & & & & ref. & & \\
\hline Large artery disease & 4.99 & 3.22 & 7.73 & $<0.001$ & 4.98 & 3.227 .72 & $<0.001$ \\
\hline Cardioembolism & 5.29 & 2.60 & 10.79 & $<0.001$ & 5.36 & 2.6310 .93 & $<0.001$ \\
\hline
\end{tabular}

In Model 1, current smokers were compared with non-smokers. In Model 2, current smokers and former smokers were compared with never-smokers. NIHSS, National Institutes of Health Stroke Scale; BMI, body mass index. 
Supplementary Table 3. Factors associated with functional outcomes in the univariate analysis

\begin{tabular}{|c|c|c|c|c|c|}
\hline Parameters & $m R S 0-1 n=670$ & $m R S 2-6 n=447$ & $\mathrm{OR}$ & $95 \% \mathrm{Cl}$ & $P$ value \\
\hline Onset-to-admission time (hour), (mean \pm SD) & $30.1 \pm 38.0$ & $24.9 \pm 35.6$ & 0.96 & 0.921 .00 & 0.007 \\
\hline Males, n (\%) & $227(50.8)$ & $220(49.2)$ & 0.58 & $0.46 \quad 0.74$ & $<0.001$ \\
\hline Age (mean \pm SD) & $63.1 \pm 13.0$ & $68.6 \pm 13.5$ & 1.38 & 1.251 .52 & $<0.001$ \\
\hline Body mass index $\left(\mathrm{kg} / \mathrm{m}^{2}\right)$, (mean $\left.\pm \mathrm{SD}\right)$ & $24.1 \pm 3.2$ & $23.1 \pm 3.1$ & 0.90 & $0.87 \quad 0.94$ & $<0.001$ \\
\hline High BMI ( $\geq 25), n(\%)$ & $248(37.7)$ & $107(25.1)$ & 0.58 & $0.44 \quad 0.77$ & $<0.001$ \\
\hline Normal BMI (ref.), n (\%) & $355(54.0)$ & $263(61.7)$ & ref. & ref. ref. & \\
\hline Low BMI (<20), n (\%) & $55(8.4)$ & $56(13.1)$ & 1.37 & $0.92 \quad 2.06$ & 0.124 \\
\hline Current smokers, n (\%) & $215(32.1)$ & $121(27.3)$ & 0.79 & 0.611 .03 & 0.082 \\
\hline Non-smokers, n (\%) & $454(67.9)$ & $323(72.7)$ & ref. & ref. ref. & \\
\hline Current smokers, n (\%) & $215(32.1)$ & $121(27.3)$ & 0.79 & 0.611 .04 & 0.097 \\
\hline Former smokers, n (\%) & $73(10.9)$ & $53(11.9)$ & 1.03 & 0.701 .51 & 0.902 \\
\hline Never-smokers, n (\%) & $381(57.0)$ & $270(60.8)$ & ref. & ref. ref. & \\
\hline Hypertension, n (\%) & $402(60.0)$ & $291(65.1)$ & 1.24 & $0.97 \quad 1.59$ & 0.085 \\
\hline Diabetes mellitus, n (\%) & $183(27.3)$ & $148(33.1)$ & 1.32 & 1.021 .71 & 0.038 \\
\hline Hyperlipidemia, n (\%) & $225(33.6)$ & $110(24.6)$ & 0.65 & $0.49 \quad 0.84$ & 0.001 \\
\hline Atrial fibrillation, $\mathrm{n}(\%)$ & $100(15.0)$ & $132(29.6)$ & 2.39 & $1.78 \quad 3.20$ & $<0.001$ \\
\hline \multicolumn{6}{|l|}{ Stroke subtype, n (\%) } \\
\hline Small vessel disease & 271 (47.8) & $89(23.7)$ & ref. & ref. ref. & \\
\hline Large artery disease & $183(32.3)$ & $155(41.3)$ & 2.58 & $1.87 \quad 3.56$ & $<0.001$ \\
\hline Cardioembolism & $113(19.9)$ & $131(34.9)$ & 3.53 & 2.495 .00 & $<0.001$ \\
\hline Received tPA thrombolysis, $\mathrm{n}(\%)$ & $39(5.8)$ & $54(12.1)$ & 2.22 & $1.45 \quad 3.42$ & $<0.001$ \\
\hline Initial NIHSS $\leq 1$ & $279(41.6)$ & $52(11.6)$ & ref. & ref. ref. & \\
\hline $2-3$ & $225(33.6)$ & $72(16.1)$ & 1.72 & 1.152 .56 & 0.008 \\
\hline $4-8$ & $118(17.6)$ & $121(27.1)$ & 5.50 & 3.738 .12 & $<0.001$ \\
\hline$\geq 9$ & $48(7.2)$ & $202(45.2)$ & 22.58 & 14.6634 .78 & $<0.001$ \\
\hline Initial systolic BP (mean \pm SD) & $141 \pm 24$ & $146 \pm 24$ & 1.09 & 1.041 .15 & 0.001 \\
\hline Fasting glucose (mg/dL), (mean $\pm S D)$ & $113 \pm 42$ & $127 \pm 55$ & 1.07 & 1.041 .10 & $<0.001$ \\
\hline LDL - cholesterol (mg/dL), (mean \pm SD) & $117 \pm 36$ & $115 \pm 37$ & 0.98 & 0.951 .01 & 0.246 \\
\hline $\mathrm{WBC}\left(/ \mathrm{mm}^{3}\right)_{1}($ mean $\pm \mathrm{SD})$ & $7,802 \pm 2,367$ & $8,871 \pm 3,348$ & 1.13 & 1.081 .17 & $<0.001$ \\
\hline Hemoglobin (g/dL), (mean $\pm S D)$ & $13.8(1.8)$ & $13.4(2.1)$ & 0.78 & $0.57 \quad 0.98$ & 0.001 \\
\hline
\end{tabular}

In these analysis, there were missing data for atrial fibrillation in 3 patients (0.3\%), smoking status in $4(0.36 \%)$, BMl in $33(3.0 \%)$, WBC in one (0.1\%), LDL-C in $22(2.0 \%)$, and fasting glucose in $98(8.8 \%)$ patients.

BMI, body mass index; BP, blood pressure; LDL, low density lipoprotein; NIHSS, National Institutes of Health Stroke Scale; tPA, tissue plasminogen activator; WBC, white blood cell. 
Supplementary Table 4. Factors associated with 3-month death in the univariate analysis

\begin{tabular}{|c|c|c|c|c|c|}
\hline \multirow{2}{*}{$\begin{array}{l}\text { Parameters } \\
\text { Onset-to-admission time (hour), (mean } \pm \text { SD) }\end{array}$} & \multirow{2}{*}{$\begin{array}{c}\text { No death } n=1,042 \\
29.3 \pm 37.4\end{array}$} & \multirow{2}{*}{$\begin{array}{c}\text { Death } n=75 \\
18.0 \pm 31.3\end{array}$} & \multirow{2}{*}{$\begin{array}{l}\mathrm{OR} \\
0.89\end{array}$} & $95 \% \mathrm{Cl}$ & \multirow{2}{*}{$\begin{array}{r}P \text { value } \\
0.013\end{array}$} \\
\hline & & & & $0.81 \quad 0.98$ & \\
\hline Males, n (\%) & $610(58.5)$ & $29(38.7)$ & 0.45 & $0.28 \quad 0.72$ & 0.001 \\
\hline Age $($ mean $\pm S D)$ & $64.5 \pm 13.3$ & $76.6 \pm 10.9$ & 2.47 & $1.92 \quad 3.17$ & $<0.001$ \\
\hline Body mass index $\left(\mathrm{kg} / \mathrm{m}^{2}\right)$, (mean $\left.\pm \mathrm{SD}\right)$ & $23.8 \pm 3.2$ & $23.1 \pm 3.6$ & 0.93 & $0.86 \quad 1.01$ & 0.083 \\
\hline High BMI ( $\geq 25), n(\%)$ & $336(33.1)$ & $19(27.9)$ & 0.86 & $0.49 \quad 1.52$ & 0.611 \\
\hline Normal BMI (ref.), n (\%) & $580(57.1)$ & $38(55.9)$ & ref. & ref. & \\
\hline Low BMI (<20), n (\%) & $100(9.8)$ & $11(16.2)$ & 0.86 & $0.49 \quad 1.52$ & 0.611 \\
\hline Current smokers, n (\%) & $326(31.4)$ & $10(13.3)$ & 0.34 & $0.17 \quad 0.66$ & 0.001 \\
\hline Non-smokers, n (\%) & $712(68.6)$ & $65(86.7)$ & ref. & ref. ref. & \\
\hline Current smokers, n (\%) & $326(31.4)$ & $10(13.3)$ & 0.36 & $0.18 \quad 0.72$ & 0.004 \\
\hline Former smokers, n (\%) & $112(10.8)$ & $14(18.7)$ & 1.47 & $0.79 \quad 2.75$ & 0.226 \\
\hline Never-smokers, n (\%) & $600(57.8)$ & $51(68.0)$ & ref. & ref. ref. & \\
\hline Hypertension, n (\%) & $641(61.5)$ & $52(69.3)$ & 1.41 & $0.85 \quad 2.35$ & 0.180 \\
\hline Diabetes mellitus, n (\%) & $308(29.6)$ & $23(30.7)$ & 1.05 & $0.63 \quad 1.75$ & 0.839 \\
\hline Hyperlipidemia, n (\%) & $323(31.0)$ & $12(16.0)$ & 0.42 & $0.23 \quad 0.80$ & 0.008 \\
\hline Atrial fibrillation, $\mathrm{n}(\%)$ & $193(18.6)$ & $39(52.0)$ & 4.75 & $2.94 \quad 7.67$ & $<0.001$ \\
\hline \multicolumn{6}{|l|}{ Stroke subtype, n (\%) } \\
\hline Small vessel disease & $356(40.1)$ & $4(7.3)$ & ref. & ref. & \\
\hline Large artery disease & $322(36.3)$ & $16(29.1)$ & 4.42 & 1.4613 .37 & 0.008 \\
\hline Cardioembolism & $209(23.6)$ & $35(63.6)$ & 14.90 & $5.22 \quad 42.53$ & $<0.001$ \\
\hline Received tPA thrombolysis, $\mathrm{n}(\%)$ & $79(7.6)$ & $14(18.7)$ & 2.80 & $1.50 \quad 5.22$ & 0.001 \\
\hline Initial NIHSS $\leq 1$ & $329(31.6)$ & $2(2.7)$ & ref. & ref. ref. & \\
\hline $2-3$ & $291(27.9)$ & $6(8.0)$ & 3.39 & 0.6816 .94 & 0.137 \\
\hline $4-8$ & $232(22.3)$ & $7(9.3)$ & 4.96 & 1.0224 .11 & 0.047 \\
\hline$\geq 9$ & $190(18.2)$ & $60(80.0)$ & 51.95 & 12.56214 .93 & $<0.001$ \\
\hline Initial systolic BP (mean \pm SD) & $142 \pm 24$ & $147 \pm 25$ & 1.08 & $0.98 \quad 1.19$ & 0.104 \\
\hline Fasting glucose (mg/dL), (mean \pm SD) & $117 \pm 46$ & $146 \pm 60$ & 1.08 & 1.041 .13 & $<0.001$ \\
\hline LDL - cholesterol (mg/dL), (mean \pm SD) & $117 \pm 36$ & $109 \pm 36$ & 0.94 & $0.97 \quad 1.01$ & 0.072 \\
\hline WBC $\left(/ \mathrm{mm}^{3}\right)$, (mean $\left.\pm \mathrm{SD}\right)$ & $8,097 \pm 2,853$ & $10,089 \pm 4,036$ & 1.19 & $1.12 \quad 1.27$ & $<0.001$ \\
\hline Hemoglobin (g/dL), (mean $\pm S D$ ) & $13.7(1.9)$ & $12.8(2.3)$ & 0.29 & $0.18 \quad 0.39$ & $<0.001$ \\
\hline
\end{tabular}

In these analysis, there were missing data for atrial fibrillation in 3 patients $(0.3 \%)$, smoking status in $4(0.36 \%)$, BMl in $33(3.0 \%)$, WBC in one (0.1\%), LDL-C in $22(2.0 \%)$, and fasting glucose in $98(8.8 \%)$ patients.

BMI, body mass index; BP, blood pressure; LDL, low density lipoprotein; NIHSS, National Institutes of Health Stroke Scale; tPA, tissue plasminogen activator; WBC, white blood cell. 
Supplementary Table 5. Adjusted odd ratio for poor functional outcome in different subgroups

\begin{tabular}{|c|c|c|c|c|c|c|}
\hline \multicolumn{2}{|l|}{ Subgroups } & \multirow{2}{*}{$\begin{array}{c}\text { Smoking status } \\
\text { Current vs. non-smoker }\end{array}$} & \multirow{2}{*}{$\begin{array}{c}\text { Adjusted OR } \\
1.13\end{array}$} & \multicolumn{2}{|c|}{$95 \% \mathrm{Cl}$} & \multirow{2}{*}{$\begin{array}{l}P \text { value } \\
0.643\end{array}$} \\
\hline Sex & Male, $n=639$ & & & 0.67 & 1.92 & \\
\hline & & Current vs. never-smoker & 1.34 & 0.75 & 2.40 & 0.328 \\
\hline & Female, $n=478$ & Current vs. non-smoker & 1.09 & 0.36 & 3.32 & 0.089 \\
\hline & & Current vs. never-smoker & 1.07 & 0.35 & 3.28 & 0.906 \\
\hline \multirow[t]{4}{*}{ Age } & Young (<65), $n=483$ & Current vs. non-smoker & 1.31 & 0.69 & 2.51 & 0.408 \\
\hline & & Current vs. never-smoker & 1.52 & 0.73 & 3.14 & 0.262 \\
\hline & Elderly ( $65 \leq$ ), $n=634$ & Current vs. non-smoker & 1.07 & 0.57 & 2.04 & 0.826 \\
\hline & & Current vs. never-smoker & 1.26 & 0.63 & 2.54 & 0.515 \\
\hline \multirow[t]{6}{*}{ Stroke subtype } & SVO, $n=360$ & Current vs. non-smoker & 0.42 & 0.09 & 1.87 & 0.253 \\
\hline & & Current vs. never-smoker & 2.41 & 0.94 & 6.15 & 0.066 \\
\hline & LVD, $n=338$ & Current vs. non-smoker & 1.04 & 0.53 & 2.05 & 0.903 \\
\hline & & Current vs. never-smoker & 1.01 & 0.47 & 2.17 & 0.975 \\
\hline & $C E, n=244$ & Current vs. non-smoker & 1.71 & 0.58 & 5.09 & 0.333 \\
\hline & & Current vs. never-smoker & 1.88 & 0.60 & 5.87 & 0.279 \\
\hline \multirow[t]{4}{*}{ Hypertension } & Yes, $n=693$ & Current vs. non-smoker & 1.43 & 0.79 & 2.60 & 0.242 \\
\hline & & Current vs. never-smoker & 1.61 & 0.83 & 3.11 & 0.156 \\
\hline & No, $n=424$ & Current vs. non-smoker & 1.24 & 0.62 & 2.50 & 0.546 \\
\hline & & Current vs. never-smoker & 1.43 & 0.67 & 3.08 & 0.359 \\
\hline \multirow{4}{*}{ Diabetes mellitus } & Yes, $n=331$ & Current vs. non-smoker & 0.97 & 0.43 & 2.19 & 0.943 \\
\hline & & Current vs. never-smoker & 1.33 & 0.54 & 3.28 & 0.534 \\
\hline & No, $n=786$ & Current vs. non-smoker & 1.72 & 1.00 & 2.96 & 0.050 \\
\hline & & Current vs. never-smoker & 1.81 & 0.99 & 3.29 & 0.052 \\
\hline \multirow[t]{4}{*}{ Hyperlipidemia } & Yes, $n=335$ & Current vs. non-smoker & 1.07 & 0.48 & 2.37 & 0.875 \\
\hline & & Current vs. never-smoker & 1.38 & 0.57 & 3.35 & 0.472 \\
\hline & No, $n=782$ & Current vs. non-smoker & 1.53 & 0.89 & 2.63 & 0.128 \\
\hline & & Current vs. never-smoker & 1.62 & 0.89 & 2.94 & 0.116 \\
\hline \multirow[t]{4}{*}{ Atrial fibrillation } & Yes, $n=232$ & Current vs. non-smoker & 2.04 & 0.49 & 8.54 & 0.328 \\
\hline & & Current vs. never-smoker & 1.41 & 0.84 & 2.38 & 0.192 \\
\hline & No, $n=882$ & Current vs. non-smoker & 1.25 & 0.78 & 2.00 & 0.348 \\
\hline & & Current vs. never-smoker & 2.21 & 0.49 & 9.91 & 0.302 \\
\hline \multirow[t]{6}{*}{ Body mass index } & $\operatorname{High}\left(\geq 25 \mathrm{~kg} / \mathrm{m}^{2}\right), n=355$ & Current vs. non-smoker & 2.04 & 0.84 & 4.96 & 0.114 \\
\hline & & Current vs. never-smoker & 1.80 & 0.70 & 4.62 & 0.221 \\
\hline & Normal, n=618 & Current vs. non-smoker & 1.03 & 0.59 & 1.81 & 0.915 \\
\hline & & Current vs. never-smoker & 1.29 & 0.69 & 2.40 & 0.431 \\
\hline & $\operatorname{Low}\left(<20 \mathrm{~kg} / \mathrm{m}^{2}\right), \mathrm{n}=111$ & Current vs. non-smoker & 7.06 & 0.91 & 54.48 & 0.061 \\
\hline & & Current vs. never-smoker & 18.34 & 1.38 & 244.03 & 0.028 \\
\hline \multirow[t]{4}{*}{ tPA therapy } & Yes, $n=93$ & Current vs. non-smoker & 4.32 & 0.65 & 28.64 & 0.129 \\
\hline & & Current vs. never-smoker & 15.33 & 1.30 & 180.20 & 0.030 \\
\hline & No, $n=1024$ & Current vs. non-smoker & 1.37 & 0.86 & 2.19 & 0.186 \\
\hline & & Current vs. never-smoker & 1.51 & 0.90 & 2.52 & 0.116 \\
\hline
\end{tabular}

SVO, small vessel disease; LVD, large artery disease; CE, cardioembolism; tPA, tissue plasminogen activator. 
Supplementary Table 6. Baseline characteristics of patients with missing data

\begin{tabular}{|c|c|c|c|c|c|c|}
\hline Parameters & $\begin{array}{l}\text { Patients with FBS data } \\
\qquad n=1,019\end{array}$ & $\begin{array}{l}\text { Patients without FBS data } \\
\qquad n=98\end{array}$ & $P$ value & $\begin{array}{l}\text { Patients with BMI data } \\
\qquad n=1,084\end{array}$ & $\begin{array}{l}\text { Patients without BMI data } \\
\qquad n=33\end{array}$ & $P$ value \\
\hline Onset-to-admission time (hour), (mean \pm SD) & $28.2(37.0)$ & $32.0(40.3)$ & 0.331 & $28.1(36.7)$ & $43.4(46.3)$ & 0.020 \\
\hline \multicolumn{7}{|l|}{ Demographics } \\
\hline Sex:males, n (\%) & $590(57.9)$ & $49(50.0)$ & 0.131 & $623(57.5)$ & $16(48.5)$ & 0.304 \\
\hline Age $($ mean $\pm S D)$ & $65.3(13.5)$ & $65.4(13.3)$ & 0.952 & $65.2(13.5)$ & $70.3(12.4)$ & 0.030 \\
\hline Body mass index $\left(\mathrm{kg} / \mathrm{m}^{2}\right)$, (mean $\left.\pm \mathrm{SD}\right)$ & $23.8(3.2)$ & $23.4(3.4)$ & 0.327 & & & \\
\hline High BMI ( $\geq 25), n(\%)$ & $328(33.1)$ & $27(28.7)$ & 0.656 & & & \\
\hline Normal BMI, n (\%) & $562(56.8)$ & $56(59.6)$ & & & & \\
\hline Low BMI (<20), n (\%) & $100(10.1)$ & $11(11.7)$ & & & & \\
\hline \multicolumn{7}{|l|}{ Smoking status, n (\%) } \\
\hline Current smoker & $306(30.1)$ & $30(30.6)$ & 0.924 & $328(30.4)$ & $8(24.2)$ & 0.450 \\
\hline Non-smoker & $709(69.9)$ & $68(69.4)$ & & $752(69.6)$ & $25(75.8)$ & \\
\hline Former smoker & $117(11.5)$ & $9(9.2)$ & & $122(11.3)$ & $4(12.1)$ & \\
\hline Never-smoker & 592 (58.3) & $59(60.2)$ & & $630(58.3)$ & $21(63.6)$ & \\
\hline Hypertension, n (\%) & $634(62.2)$ & $59(60.2)$ & 0.695 & $672(62.0)$ & $21(63.6)$ & 0.848 \\
\hline Diabetes mellitus, $\mathrm{n}(\%)$ & $301(29.5)$ & $30(30.6)$ & 0.824 & $320(29.5)$ & $11(33.3)$ & 0.637 \\
\hline Hyperlipidemia, n (\%) & $311(30.5)$ & $24(24.5)$ & 0.213 & $328(30.3)$ & $7(21.2)$ & 0.264 \\
\hline Atrial fibrillation, $\mathrm{n}(\%)$ & $210(20.7)$ & $22(22.4)$ & 0.679 & $226(20.9)$ & $6(18.2)$ & 0.704 \\
\hline \multicolumn{7}{|l|}{ Stroke subtype, n (\%) } \\
\hline Large artery disease & $318(36.9)$ & $20(24.7)$ & 0.070 & $326(35.7)$ & $12(40.0)$ & 0.841 \\
\hline Small vessel disease & $326(37.9)$ & $34(42.0)$ & & $350(38.4)$ & $10(33.3)$ & \\
\hline Cardioembolism & $217(25.2)$ & $27(33.3)$ & & $236(25.9)$ & $8(26.7)$ & \\
\hline Received tPA thrombolysis, $n(\%)$ & $85(8.3)$ & $8(8.2)$ & 0.951 & $91(8.4)$ & $2(6.1)$ & 0.633 \\
\hline Initial NIHSS score (mean \pm SD) & $5.4(6.0)$ & $5.7(7.1)$ & 0.593 & $5.4(6.1)$ & $6.7(6.9)$ & 0.231 \\
\hline Initial NIHSS $\leq 1$ & $303(29.7)$ & $28(28.6)$ & 0.630 & $323(29.8)$ & $8(24.2)$ & 0.427 \\
\hline $2-3$ & 273 (26.8) & $24(24.5)$ & & 288 (26.6) & $9(27.3)$ & \\
\hline $4-8$ & $213(20.9)$ & $26(26.5)$ & & 234 (21.6) & $5(15.2)$ & \\
\hline$\geq 9$ & $230(22.6)$ & $20(20.4)$ & & $239(22.0)$ & $11(33.3)$ & \\
\hline
\end{tabular}

FBS, fasting blood sugar; BMI, body mass index; NIHSS, National Institutes of Health Stroke Scale; tPA, tissue plasminogen activator. 